\title{
Insecticidal activity of essential oils in controlling fall armyworm, Spodoptera frugiperda
}

\author{
Atividade inseticida de óleos essenciais para o controle \\ da lagarta-do-cartucho do milho, Spodoptera frugiperda
}

\author{
Marcelo Negrini 1* (D), Elisangela Gomes Fidelis ${ }^{2}$ (D), Daniel Augusto Schurt ${ }^{2}$ (D), \\ Francisco dos Santos Silva' ${ }^{1}$, Rosely Souza Pereira ${ }^{3}$ (D), Humberto Ribeiro Bizzo ${ }^{4}$
}

\begin{abstract}
Fall armyworm, Spodoptera frugiperda (Smith) (Lepidoptera: Noctuidae) is one of the main pests in maize crop with developing resistance to chemical products and Bt technology. Therefore, alternative control methods such as essential oils are important steps in the implementation management strategies for this pest. This study aimed to evaluate the efficiency of essential oils (EOs) of Corymbia citriodora, Myrciaria dubia (Myrtaceae), Lippia microphylla (Verbenaceae) and Piper umbelattum (Piperaceae) in controlling $S$. frugiperda. The OEs were extracted and mortality tests were conducted with topic and volatile applications, in 30 second-instar caterpillars originated from insect rearing and artificial diet. As a control, we conducted tests with distilled water and acetone. EOs that provided mortality rates above $80 \%$ were submitted to chemical analysis for constituent identification. The efficient EOs were only those of C. citriodora and L. microphylla. For EO of C. citriodora, the LD80 was $7.06 \pm 0.73 \mathrm{mg} . \mathrm{g}^{-1}$ in topical application and $5.85 \pm$ $0.75 \mu \mathrm{L}$ via volatile application. On the other hand, for $\mathrm{EO}$ of $L$. microphylla, DL80 was $9.95 \pm 1.25 \mathrm{mg} \cdot \mathrm{g}^{-1}$ in topical application and $18.56 \pm 3.55 \mu \mathrm{L}$ via volatile application. Chemical analysis showed that the main constituents were citronella for the EO of C. citriodora and (E)-caryophyllene and (E)-nerolidol to the $\mathrm{EO}$ of L. microphylla. EOs of C. citriodora and L. microphylla are promising for controlling $S$. frugiperda, with emphasis on the volatile effect of $C$. citriodora oil.
\end{abstract}

KEYWORDS: Spodoptera frugiperda; integrated pest management; Lippia microphylla; Corymbia citriodora.
RESUMO: A lagarta-do-cartucho, Spodoptera frugiperda (Lepdoptera: Noctuidae), é uma das principais pragas na cultura do milho e nos últimos anos vem desenvolvendo resistência a produtos químicos è̀ tecnologia Bt. Métodos alternativos de controle, como o emprego de óleos essenciais, são um passo importante na implementaçáo de estratégias de manejo para essa praga. O objetivo deste trabalho foi avaliar a eficiência dos óleos essenciais de Corymbia citriodora, Myrciaria dubia (Myrtaceae), Lippia microphylla (Verbenaceae) e Piper umbelattum (Piperaceae) no controle de $S$. frugiperda. Os óleos essenciais foram extraídos e testes de mortalidade com aplicação tópica e de voláteis foram conduzidos com 30 lagartas de segundo instar provenientes de criação massal e em dieta artificial. Como testemunha, foram conduzidos testes com água destilada e acetona. Os óleos essenciais que proporcionaram taxas de mortalidade acima de $80 \%$ foram submetidos à análise química para identificação de seus constituintes. Entre os óleos essenciais, mostraram-se eficientes apenas os de $C$. citriodora e L. microphylla. Para o óleo essencial de C. citriodora, a DL80 foi de $7,06 \pm 0,73 \mathrm{mg} \cdot \mathrm{g}^{-1} \mathrm{em}$ aplicação tópica e 5,85 $\pm 0,75 \mu \mathrm{L}$ via aplicação do volátil. Já para o óleo essencial de L. microphylla, a DL80 foi de $9,95 \pm 1,25 \mathrm{mg} \cdot \mathrm{g}^{-1} \mathrm{em}$ aplicaçáo tópica e $18,56 \pm 3,55 \mu \mathrm{L}$ via aplicação do volátil. A análise química demonstrou que os principais constituintes foram citronelal para o óleo essencial de C. citriodora, e (E)-cariofileno e (E)-nerolidol para o de L. microphylla. Os óleos essenciais de C. citriodora e L. microphylla são promissores para o controle de $S$. frugiperda, com destaque para o efeito volátil do óleo de $C$. citriodora.

PALAVRAS-CHAVE: Spodoptera frugiperda; manejo integrado de pragas; Lippia microphylla; Corymbia citriodora. 


\section{INTRODUCTION}

Fall armyworm, Spodoptera frugiperda (Smith, 1797) (Lepdoptera: Noctuidae) is a polyphagous insect, one of the most important pests for maize in South America (POGUE, 2002). In Roraima, S. frugiperda is a pest for crops of rice (SAKAZAKI et al., 2008) and maize (MARSARO JUNIOR; SILVA JUNIOR, 2010; MASTRANGELO et al., 2014). These crops represent $36 \%$ of the planted area and $58 \%$ of the agricultural production in the state on annual plantings (CONAB, 2017). Despite the prominence given to $S$. frugiperda as maize pest, this species has been reported in other crops such as sorghum, Sorghumbicolor (L.) Moench, pasture Panicum maximum Jacq. Cv. Tanzânia, sugarcane, Saccharum officinarum L. (Poaceae) cotton, Gossypium herbaceum L. (Malvaceae) and soy, Glycine $\max ($ L.) Merril (Fabaceae) (BOREGAS et al., 2013).

The control of $S$. frugiperda intensified the use of pyrethroids and organophosphates in crops, reducing control efficiency and resistance against $S$. frugiperda to these chemical groups (CARVALHO et al., 2013). Resistance cases have already been reported for lambda-cyhalothrin (DIEZ-RODRÍGUEZ; OMOTO, 2001), chlorpyrifos (CARVALHO et al., 2013) and lufenuron (NASCIMENTO et al., 2016). In addition, there are cases of selection of individuals of $S$. frugiperda resistant to maize with the gene Bt (Bacillus thurigiencis), toxins Cry1F and Cry1Ab (FARIAS et al., 2014; OMOTO et al., 2016; BURTET et al., 2017). In this sense, the use of alternative methods such as plant extracts and essential oils to control insect pests has been increasing (KRINSKI et al., 2014).

Botanic insecticides control pests since ancient times (VIEGAS JÚNIOR, 2003). These phyto-insecticides, in the form of plant extracts and essential oils, are an excellent alternative for pest management in a diverse flora such as in Brazil, and therefore, with a high potential for the discovery of new insecticides (KRINSKI et al., 2014). The essential oils (EOs) of some species may present toxic compounds for insects, but are safe for humans, thus with a high potential to control agricultural pests (EBADOLLAHI, 2011).

Some EOs extracted from certain plant species have the capacity to repel and/or kill through direct contact and even through the respiratory system (ISMAN, 2000; CORRÊA; SALGADO, 2011). The secondary metabolism of the plants synthesize these oils using all their organs and have a communication (e.g., attracting pollinators) and defense function (BAKKALI et al., 2008). In addition, they present the following advantages: high efficiency, numerous modes of action, low toxicity to non-target organisms and potential use as by-products (PAVELA; BENELLI, 2016). In their composition, EOs can have from 20 to 60 components, of which only two or three can represent $20-70 \%$ of the oil composition (BAKKALI et al., 2008).

To control S. frugiperda, the efficiency of leaf extract and branches of Trichilia pallida Sw (Meliaceae) in ethyl acetate (ROEL et al., 2000) and aqueous extract of leaves of nim (Azadirachta indica A. Juss. - Meliaceae) (VIANA; PRATES, 2003) via digestion was showed. EOs of Corymbia citriodora (Hook.) K.D. Hill \& L.A.S. Johnson (SOUZA et al., 2010; ZHANG et al., 2014), of some species of the genus Piper spp. (SCOTT et al., 2008) and Lippia alba (Mill.) N.E.Br. ex Britton \& P. Wilson (Verbanaceae) (NICULAU et al., 2013) have also shown to be efficient in controlling $S$. frugiperda in topical applications.

The potential to develop phyto-insecticides from EOs is enormous in Brazil, especially due to the richness and diversity of flora (KRINSKI et al., 2014). In addition, studies on potential insecticides in the country from EOs are scarce. Therefore, this study aimed to evaluate the efficiency of EOs of Corymbia citriodora, Lippiamicrophylla Cham., Piper umbelattum L. and Myrciaria dubia (Kunth) McVaugh in controlling S. frugiperda.

\section{MATERIAL AND METHODS}

\section{Laboratory rearing of S. frugiperda}

Adults of $S$. frugiperda were caught with light trap in the maize cultivation area of the Experimental Field of Embrapa Roraima ( $2^{\circ} 40^{\prime} 01.3$ ” N 60 50'24”W), municipality of Boa Vista, Roraima state, and taken to the Entomology Laboratory of Embrapa Roraima. These were packed in acrylic cages with the sidewalls covered with kraft paper to oviposition. The cages were maintained at $27 \pm 2^{\circ} \mathrm{C}, 65 \pm 5 \%$ relative humidity and totally in the dark. The moths were fed with a solution of distilled water and honey $10 \%$ soaked in cotton. The egg masses were removed from the paper daily and transferred to an artificial diet (GREENE et al., 1976). After hatching, the caterpillars were individualized in $50 \mathrm{~mL}$ plastic bottles, with artificial diet, one part was used in the experiment and the other was maintained for breeding.

Adult moths were sent to Dr. Alexandre Specht (Embrapa Cerrados, Brasília, DF), who confirmed the identification of the species.

\section{Essential oils extraction}

Leaves of Corymbia citriodora, Lippia microphylla, Piper umbelattum and Myrciaria dubia were collected at the headquarters

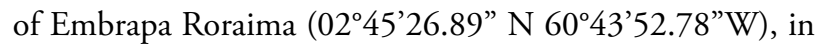
the early hours of the morning. We selected the leaves with the best physical and sanitary appearance and took them to the Laboratory of Soil Chemistry and Fertility of Campus Murupu.

We sanitized $300 \mathrm{~g}$ of fresh leaves with distilled water for extraction by hydro distillation technique, using a clevenger apparatus by Vidrolabor, with closed water circuit. We placed the leaves in a 3,000 $\mathrm{mL}$ round bottom flask and added about $2,000 \mathrm{~mL}$ of distilled water as solvent. Heating mantle was used as a heat source, and a thermostat bath as a refrigerator. 
After 3 hours of extraction, the EOs were obtained and collected in amber glass bottles suitably tared and treated with sodium sulfate $\mathrm{Na}_{2} \mathrm{SO}_{4}$ anhydride, to remove humidity (MEDEIROS et al., 2016).

\section{Bioassays with topical application}

We performed initial bioassays, with application of 30 milligrams of oil per gram of insect mg. $\mathrm{g}^{-1}$ ), to select the most lethal EOs. EOs that caused mortality greater than $80 \%$ were diluted in acetone at $1,5,10,15$ and $20 \mathrm{mg} \cdot \mathrm{g}^{-1}$ concentrations for dose-response curves.

For each dosage, we used 30 second-instar caterpillars obtained from the mass rearing and individualized in plastic bottles of $50 \mathrm{~mL}$ with artificial diet. Each caterpillar received $1 \mu \mathrm{L}$ of solution using a Hamilton microsyringe.

Caterpillar mortality was monitored daily for 10 days, and those that did not show movements after a touch with a brush of fine bristles were considered dead.

\section{Bioassays with volatiles}

The effects of volatile substances from EOs that have caused mortality above $80 \%$ in topical application tests have also been tested. Therefore, we weighted the volume of $100 \mu \mathrm{L}$ of each $\mathrm{EO}$ in a precision scale, thus obtaining the weight/volume for each $\mathrm{EO}(\mathrm{mg} / 100 \mu \mathrm{L})$. With this value, we estimated the volume of $\mathrm{EO}$ that corresponded to the concentrations of $1,5,10,15,20$ and $30 \mathrm{mg} \cdot \mathrm{g}^{-1}$ by the following equation 1 :

Estimated volume $=\frac{\text { Concentration }}{\text { Weigth } / \text { volume }}$

In which the estimated volume is the quantity in $\mu \mathrm{L}$ of EO to be applied; the concentration refers to the values of 1 , $5,10,15,20$ and $30 \mathrm{mg} \cdot \mathrm{g}^{-1}$ and the weight/volume is weight, in mg, obtained by weighing $100 \mu \mathrm{L}$ of EO.

The EOs were applied to a 66.7 x $25.4 \mathrm{~mm}$ filter paper bonded to a Petri dish lid. The control treatment was the application of $1 \mathrm{~mL}$ of water on the label-adhesive. Each Petri dish hosted $10 \mathrm{~g}$ of the artificial diet and a second-instar caterpillar without direct contact with the treated paper. The plates were sealed with Parafilm and the caterpillars survival was evaluated daily for 10 days. For each treatment, we performed 30 replicates.

\section{Chemical composition of the essential oils}

The essential oil was analyzed by GC-FID and GC-MS in Agilent $6890 \mathrm{~N}$ and $5973 \mathrm{~N}$ systems, both with HP-5MS fused silica capillary columns ( $30 \mathrm{~m} \times 0.25 \mathrm{~mm} \times 0.25 \mu \mathrm{m}$ ). Hydrogen was used as carrier gas for GC-FID and helium for GC-MS, both with a flow rate of $1.0 \mathrm{~mL} /$ minute, and a split 1:100. Oven temperature was raised from 60 to $240^{\circ} \mathrm{C}$ at $3^{\circ} \mathrm{C} /$ minute. Mass detector was operated in electronic ionization mode at $70 \mathrm{eV}$. Quantitative data were obtained from the flame ionization detector (FID) signal corrected with response factors and with area normalization using methyl octanoate as internal standard. Oil components were identified by comparison of both mass spectra and linear retention indices with spectral library and literature.

\section{Data analysis}

For all bioassays, mortality rates of caterpillars were corrected through Abbott's formula (1925). Mortalities in the first bioassay of topical application were submitted to Kruskal-Wallis analysis, followed by the Dunn's test. These analyses took place in the $\mathrm{R}$ program (R CORE TEAM, 2017).

To obtain the dose-response curves, we submitted the mortalities obtained at each dosage 166 in the second bioassay of topical application and bioassay with volatiles to regression analysis. We used the Probit, log-logistic and logistic models with three coefficients. The selected model resulted in all the significant coefficients $(\mathrm{p}<0.05)$. These analyzes occurred in the $\mathrm{R}$ program using the package DRC (RITZ; STREIBIG, 2005; RITZ et al., 2015). Based on these models, we calculated $\mathrm{DL}_{50}, \mathrm{DL}_{80}$ and $\mathrm{DL}_{90}$.

\section{RESULTS}

The Kruskal-Wallis test indicated that mortality rate of $S$. frugiperda were statistically different $(\mathrm{p}=2.596 \mathrm{e}-05)$ with topical application of EOs at the dosage of $30 \mathrm{mg} \cdot \mathrm{g}^{-1}$. The EOs of $P$. umbelattum and $M$. dubia provided mortality rates of 0 and $6.5 \%$ respectively and were statistically equal to the control. On the other hand, EOs of $C$. citriodora and $L$. microphylla provided mortality rates of $100 \%$ (Fig. 1).

To obtain the dose-response curves, the logistic model had the best adjustment $(\mathrm{p}<0.05)$. Mortality rates, via topical application, provided by the $\mathrm{EO}$ of $C$. citriodora were higher and stabilized the curve with $10 \mathrm{mg} \cdot \mathrm{g}^{-1}$, while for the EO of $L$. microphylla, this occurred only at $15 \mathrm{mg} \cdot \mathrm{g}^{-1}$ (Figs. $2 \mathrm{~A}$ and B). The EOs of C. citriodora and of L. microphylla caused mortality rates $92 \%$ higher than the control.

In the experiment with volatiles, the logistic model also provided the best adjustment $(\mathrm{p}<0.05)$. Exposure of caterpillars at $6.4 \mu \mathrm{L}$ of $\mathrm{EO}$ of $C$. citriodora resulted in mortality higher than $80 \%$, which was stabilized with $12.7 \mu \mathrm{L}$. For the EO of $L$. microphylla this occurred with $23.5 \mu \mathrm{L}$ only (Figs. $2 \mathrm{C}$ and D).

$\mathrm{DL}_{50}, \mathrm{DL}_{80}$ and $\mathrm{DL}_{90}$ were smaller for the $\mathrm{EO}$ of C. citriodora in both bioassays (topical and volatile application). From topical application, for both $\mathrm{EOs}, \mathrm{DL}_{80}$ was obtained with dosages below $10 \mathrm{mg} \cdot \mathrm{g}^{-1} \cdot \mathrm{DL}_{80}$ and $\mathrm{DL}_{90}$ for $C$. citriodora were smaller in volatile bioassay than topical application bioassay. 


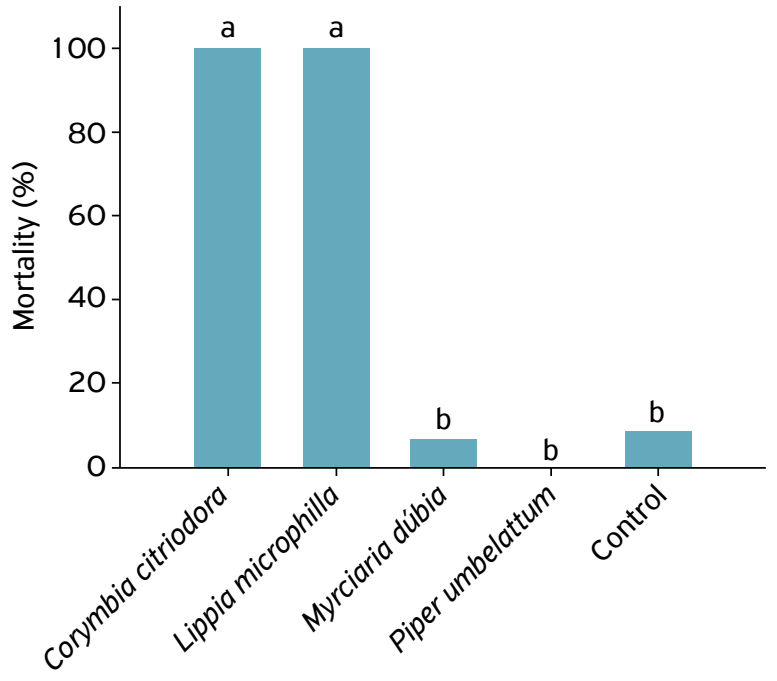

Figure 1. Mortality (\%) of Spodoptera frugiperda 10 days after the topical application of four essential oils at $30 \mathrm{mg}^{-\mathrm{g}^{-1}}$ dosage. Averages followed by the same letters do not differ by the Dunn's test at $5 \%$ probability.

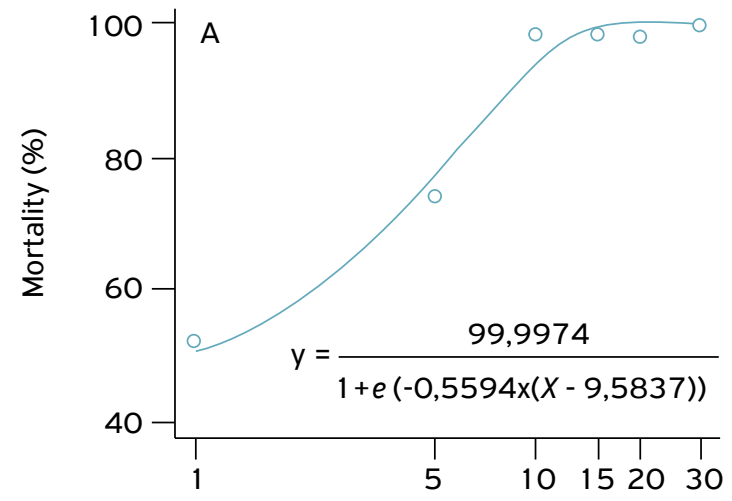

Dose $(\mathrm{mg} / \mathrm{g})$

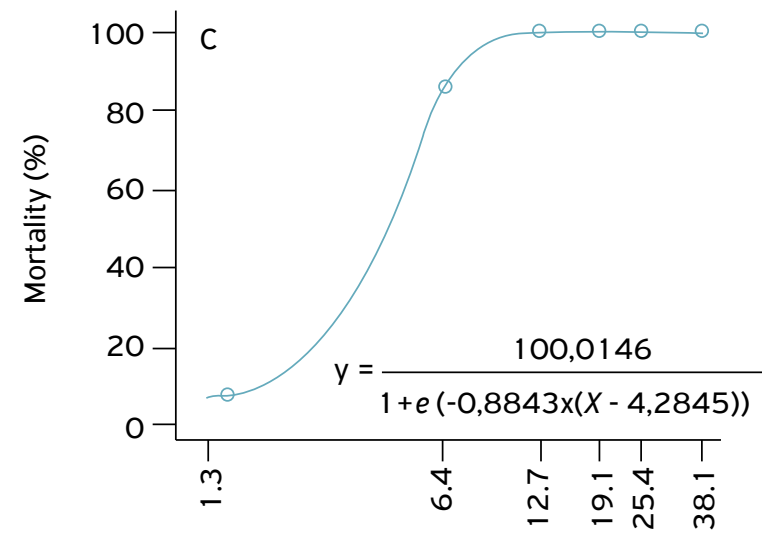

Dose $(\mu \mathrm{L})$
In contrast, for the EO of L. microphylla, the topical application was more efficient (Table 1).

In the $\mathrm{EO}$ of $C$. citriodora, we identified 11 constituents that correspond to $92.9 \%$; citronellal $(80 \%)$ is the major constituent. On the other hand, in the EO of L. microphylla, there were 25 constituents corresponding to $91.8 \%$, and the major constituents of this EO were (E)-caryophyllene (32.1\%) and (E)-nerolidol (14.1\%) (Table 2).

\section{DISCUSSION}

The EO of P. umbelattum had no insecticidal effect on the topical application bioassay. EOs from other species of this genus were toxic to pest insects, such as $P$. hispidinervum and $P$. aduncum, which is efficient to control Sitophilus zeamais (Motschulsky, 1855) (Coleoptera: Curculionidae) (ESTRELA et al. 2006); and P. hispidinervum, which has insecticidal effect on $S$. frugiperda

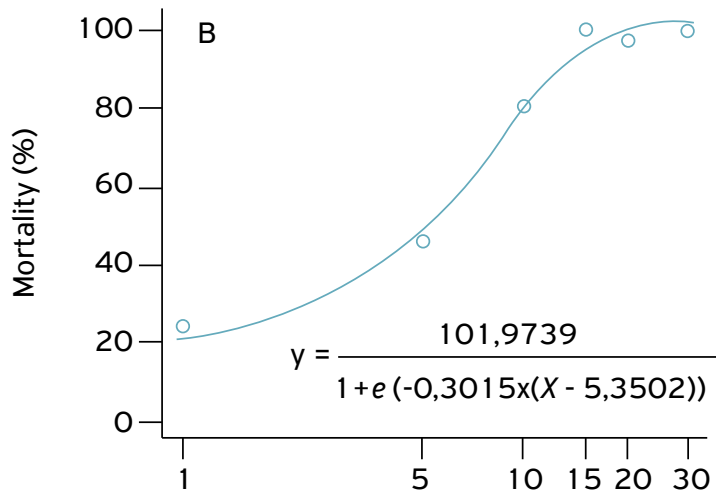

Dose $(\mathrm{mg} / \mathrm{g})$

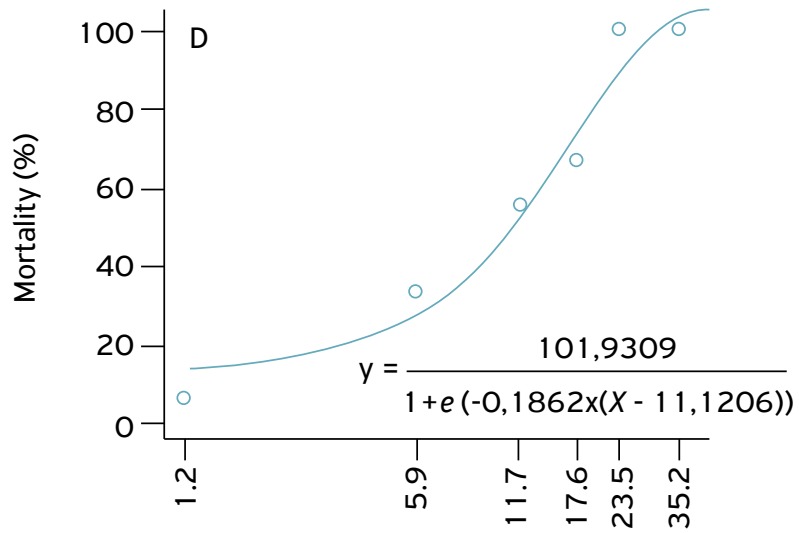

Dose $(\mu \mathrm{L})$

Figure 2. Mortality (\%) of second-instar caterpillars Spodoptera frugiperda 10 days after topical application obtained with topical applications of different dosages of essential oils of Corymbia citriodora (A) and Lippia microphylla (B) and under volatile effect Corymbia citriodora (C) and Lippia microphylla (D). 
and P. aduncum on Anticarsia gemmatalis Hübner (Lepidoptera: Noctuidae), S. frugiperda (LUCENA et al., 2017) and Euschistus heros (Fabricius, 1798) (Hemiptera: Pentatomidae) (PITON et al., 2014). The repellent effect of leaves and flowers of P. umbelattum in mosquitoes has already been reported (CHARTOL, 1964); however, its toxic effects should be better evidenced (ROERSCH, 2010). For $P$. umbelattum, the inefficiency in controlling $S$. frugiperda may be associated with the EOs chemical composition, which may change between the biotypes of the species (MATTANA et al., 2015). Studies conducted with the EO of leaves of P. umbelattum from Brazil, indicate a large constituent and concentration variation, being reported the following molecules: $(\beta)$-caryophyllene, germacrene- $\mathrm{D}$, heneicosane, (E)-nerolidol, $\alpha$ and $\beta$ pinene, bicyclogermacrene, $\delta$-cadinene, (E, E)- $\alpha$-farnesene, $\beta$-elemene and trans-dihydroagarofuran (LUZ et al., 1999; MESQUITA et al., 2005; MAIA; ANDRADE, 2009).

The EO of M. dubia was also inefficient to control S. frugiperda. Terpenes are predominant in the chemical composition of EOs of fruit of $M$. dubia, especially $\alpha$-pinene and $d$-limonene (FRANCO; SHIBAMOTO, 2000). In fact, terpenes have insecticidal activity, either through interaction with the integument or with enzymes of the digestive and even neurological systems of the insects (BAKKALI et al., 2008; ISMAN, 2000). For this work, we used leaves of $M$. dubia to extract EO, which may have chemical composition different from those of fruits and therefore, inefficient for pest control. In addition, the action of these terpenoid compounds also depends on the life stage and species of the target insect (VIEGAS JÚNIOR, 2003).

The topical and volatile application of $\mathrm{EO}$ of $C$. citriodora caused high rates of mortality in the population of $S$. frugiperda. The insecticidal activity of this EO is efficient in applications by means of fumigation and contact (JANG et al., 2016) and even in spraying (SOUZA et al., 2010). In addition, the volatile repellent effect of $\mathrm{EO}$ of $C$. citriodora were already shown for Empoasca vitis Mitjaev, 1980 (Hemiptera: Cicadellidae) (ZHANG et al., 2014). For S. frugiperda, which has a habit of hiding inside the maize cartridge, the volatile effect of the product would be an advantage, since it could easily reach the target. In addition, RIBEIRO et al. (2018) showed that the topical application of this EO in Ascia monuste (LINNAEUS, 1764) (Lepidoptera: Pieridae) provided fast mortality among the subjects (LT $50<10 \mathrm{~min}$ ). Citronellal was the main constituent of
Table 2. Chemical composition (\%) of essential oils of Corymbia citriodora and Lippia Microphylla.

\begin{tabular}{|c|c|c|}
\hline Constituent & $\begin{array}{l}\text { EO } C \text {. } \\
\text { citriodora }\end{array}$ & $\begin{array}{l}\text { EO L. } \\
\text { microphylla }\end{array}$ \\
\hline (E)-caryophyllene & 0.1 & 32.1 \\
\hline (E)-nerolidol & - & 14.1 \\
\hline (neoiso)-isopulegol & 0.1 & - \\
\hline (Z)-beta-farnesene & - & 0.4 \\
\hline (Z)-beta-ocimene & - & 0.8 \\
\hline 1.8-cineole & - & 1.5 \\
\hline alpha-alaskene & - & 3.6 \\
\hline alpha-cedrene & - & 2 \\
\hline alpha-humulene & - & 2.2 \\
\hline alpha-pinene & 0.1 & 1.4 \\
\hline Bergamal & 0.4 & - \\
\hline beta-bisabolene & - & 2 \\
\hline beta-pinene & 0.2 & - \\
\hline $\begin{array}{l}\text { caryophyll-4(12),8(13)-5-alpha } \\
\text { or 5-beta-ol }\end{array}$ & - & 0.5 \\
\hline carvacrol & - & 1.8 \\
\hline $\begin{array}{l}\text { cis-beta-guaienes + } \\
\text { alpha-zingiberene }\end{array}$ & - & 2 \\
\hline cis-calamene & - & 1 \\
\hline citronellal & 80 & - \\
\hline citronellol & 4.8 & - \\
\hline gamma-terpinene & - & 2.6 \\
\hline germacrene $D$ & - & 0.8 \\
\hline iso-isopulegol & 0.5 & - \\
\hline isopulegol & 6.2 & - \\
\hline linalool & 0.4 & 4.1 \\
\hline menthone & 0.1 & - \\
\hline caryophyllene oxide & - & 5.4 \\
\hline $\mathrm{p}$-cymene & - & 4.8 \\
\hline rosifolol & - & 1.2 \\
\hline sesquitujene & - & 1.2 \\
\hline terpinen-4-ol & - & 0.5 \\
\hline thymol & - & 2.4 \\
\hline thymol, methyl ether & - & 0.6 \\
\hline trans-calamenene & - & 2.8 \\
\hline Total identified (\%) & 92.9 & 91.8 \\
\hline
\end{tabular}

Table 1. Lethal doses of essential oil of Corymbia citriodora and Lippia microphylla for second-instar caterpillars Spodoptera frugiperda with topical and volatile application.

\begin{tabular}{lcccc}
\hline OE & Bioassays & $\mathrm{DL}_{50} \pm \mathrm{EP}$ & $\mathrm{DL}_{80} \pm \mathrm{EP}$ & $\mathrm{DL}_{90} \pm \mathrm{EP}$ \\
C. citriodora & Topital $\left(\mathrm{mg} \cdot \mathrm{g}^{-1}\right)$ & $4,59 \pm 0,44$ & $7,06 \pm 0,73$ & $8,51 \pm 1,03$ \\
\cline { 2 - 5 } & Volatile $(\mu \mathrm{L})$ & $4,28 \pm 0,76$ & $5,85 \pm 0,75$ & $6,77 \pm 0,88$ \\
\hline \multirow{2}{*}{ L. microphylla } & Topical $\left(\mathrm{mg} \cdot \mathrm{g}^{-1}\right)$ & $5,35 \pm 0,70$ & $9,95 \pm 1,25$ & $12,64 \pm 1,71$ \\
\cline { 2 - 5 } & Volatile $(\mu \mathrm{L})$ & $11,12 \pm 1,98$ & $18,56 \pm 3,55$ & $22,91 \pm 4,65$ \\
\hline
\end{tabular}


EO of C. citriodora, a corroborating result with those obtained in other studies that determined that the insecticidal activity of this EO relates to this component (SOUZA et al., 2010; JANG et al., 2016; RIBEIRO et al., 2018). Despite this, other constituents found in this EO, such as isopulegol, citronellol and $\beta$ pinene were efficient in controlling other pests (LEE et al., 2003; KAUFMAN et al., 2010; GIATROPOULOS et al., 2012). According to OLIVEIRA et al. (2017) the target species of the control and the way this target is exposed to EO influence the mortality of individuals.

The EO of L. microphylla also provided high mortality rates; however, it was more efficient in topical applications. EOs of other species of this genus were efficient, such as $L$. alba in the control of $S$. frugiperda (NICULAU et al., 2013) and $L$. gracilis to control Diaphania hyalinata (LINNAEUS, 1767) (Lepidoptera: Pyralidae) (MELO et al., 2018). L. microphylla is a shrub with simple leaves with serrated edges and printed veins (LORENZI; MATOS, 2008), which occurs throughout Brazil in the Tableland Forest, open forests, Caatinga and Cerrado (SANTOS et al., 2009). This species stands out because of its medicinal properties; however, it is still underexploited in Brazil (SIMÓES et al., 2005). In addition to the medicinal properties, the insecticidal activity of $\mathrm{EO}$ of L. microphylla stands out against $S$. frugiperda.

The insecticidal activity of EO of $L$. alba is attributed to the linalool component (NICULAU et al., 2013), whereas for EO of L. gracilis, it is attributed to thymol and carvacrol (MELO et al., 2018). Although the components mentioned belong to the chemical profile of EO of L. microphylla, its major components in this study were E-caryophyllene and E-nerolidol, respectively. XAVIER et al. (2015) found, in EO of $L$. microphylla, the following constituents: thymol, carvacrol, p-cymene and $\gamma$-terpinene; while COSTA et al. (2005) found: 1,8-cineol, thymol and $\alpha$-pinene, therefore differing from our results. On the other hand, SILVA (2014) studied the chemical composition of EO of L. microphylla of Roraima plants and verified the following major constituents: thymol, carvacrol, E-caryophyllene, nerolidol and caryophyllene oxide. According to the same author, climatic factors, such as rainfall on the day the leaves are collected, can change the chemical composition of this EO. Despite these differences, we observed insecticidal activity of $\mathrm{EO}$ of $L$. microphylla opposite to $S$. frugiperda, which can relate to the synergism between the different substances that make up this EO (BAKKALI et al., 2008).
Aspects of selectivity should be observed when using EO to non-target organisms. According to MELO et al. (2018) the $\mathrm{EO}$ of $L$. gracilis was not selective for the bee Apis mellifera Linnaeus, 1758 (Hymenoptera: Apidae) and the predatory wasp Polybia micans Ducke, 1904 (Hymenoptera: Vespidae). The EO of C. citriodora may present negative effects on pollinators (FILOMENO et al., 2017), which is harmful for Tetragonisca angustula Latreille (Hymenoptera: Apidae); however, it is harmless to Solenopsis saevissima Smith (Hymenoptera: Formicidae) (RIBEIRO et al., 2018). Therefore, for its use, there are some precautions, such as avoiding applications in the period of the most pollinator activity, such as during the hottest hours of the day (de BRUIJN; SOMMEIJER, 1997).

\section{FINAL REMARKS}

Essential oils of $P$. umbelattum and $M$. dubia were inefficient to control S. frugiperda. On the other hand, EOs of C. citriodora and L. microphylla were promising for $S$. frugiperda control, both via contact and by effect of volatiles. The essential oil of $C$. citriodora was more efficient than that of $L$. microphylla in both ways, since low volumes result in high mortality rates. Citronellal, due to its large concentration, is the main constituent in the $\mathrm{EO}$ of $C$. citriodora and can be determinant for the observed high mortality rates. E-caryophyllene and E-nerolidol were the main constituents in the EO of L. microphylla; however, both correspond to less than $50 \%$ of this $\mathrm{EO}$, thus the high mortality of caterpillars may be related to other components, such as linalol, thymol and carvacrol.

\section{ACKNOWLEDGMENTS}

This study was financed in part by the Coordenação de Aperfeiçoamento de Pessoal de Nível Superior - Brasil (CAPES) - Finance Code 001. We also thank to Embrapa and Conselho Nacional de Desenvolvimento Científico e Tecnológico (CNPq) for the resources, to the Laboratory of Soil Fertility and Chemistry of the Federal University of Roraima for the EOs Extraction, and to Dr. Alexandre Specht for identifying the caterpillar species.

\section{REFERENCES}

ABBOTT, W.S. A method of computing the effectiveness of an insecticide. Journal of Economic Entomology, v.18, n.2, p.265266, 1925. https://doi.org/10.1093/jee/18.2.265a
BAKKALI, F.; AVERBECK, S.; AVERBECK, D.; IDAOMAR, M. Biological effects of essential oils - A review. Food and Chemical Toxicology, v.46, n.2, p.446-475, 2008. https://doi.org/10.1016/j.fct.2007.09.106 
BOREGAS, K.G.B.; MENDES, A.M.; WAQUIL, J.M.; FERNANDES, G.W. Estádio de adaptação de Spodoptera frugiperda (J. E. Smith) (Lepidoptera: Noctuidae) em hospedeiros alternativos. Bragantia, v.72, n.1, p.61-70, 2013. http://dx.doi.org/10.1590/ S0006-87052013000100009

BURTET, L.M.; BERNARDI, O.; MELO, A.A.; PES, M.P.; STRAHL, T.T.; GUEDES, J.V.C. Managing fall armyworm, Spodoptera frugiperda (Lepidoptera: Noctuidae), with Bt maize and insecticides in southern Brazil. Pest Management Science, v.73. n.12, p.25692577, 2017. https://doi.org/10.1002/ps.4660

CARVALHO, R.A.; OMOTO, C.; FIELD. L.M.; WILLIAMSON, M.S.; BASS, C. Investigating the molecular mechanisms of organophosphate and pyrethroid resistance in the fall armyworm Spodoptera frugiperda. Plos One, v.8, n.4, p.e62268, 2013. https://doi. org/10.1371/journal.pone.0062268

CHARTOL, A. A review of Piper spp. (Piperaceae) phytochemistry, insecticidal activity and mode of action. Medecine Tropicale, v. 24, n.6, p.743-747, 1964.

COMPANHIA NACIONAL DE ABASTECIMENTO (CONAB). Séries históricas. Available from: <http://www.conab.gov.br/conteudos. php?a=1252>. Accessed on: 2017 Oct. 15.

CORRÊA, J.C.R.; SALGADO, H.R.N. Atividade inseticida das plantas e aplicações: revisão. Revista Brasileira de Plantas Medicinais, v.13, n.4, p.500-506, 2011 . http://dx.doi.org/10.1590/ S1516-05722011000400016

COSTA, S.M.O.; SANTOS, H.S.; PESSOA, O.D.L.; LEMOS, T.L.G. Constituents of the essential oil of Lippia microphylla CHAM. from northeast Brazil. Journal of Essential Oil Research, v.17, n.4, p.378-379, 2005. https://doi.org/10.1080/1041290 5.2005 .9698935

De BRUIJN, L.L.M.; SOMMEIJER, M.J. Colony foraging in different species of stingless bees (Apidae, Meliponinae) and the regulation of individual nectar foraging. Insectes Sociaux, v.44, n. 1, p.35-47, 1997. https://doi.org/10.1007/s000400050028

DIEZ-RODRÍGUEZ, G.I.; ОMOTO, C. Herança da resistência de Spodoptera frugiperda (J.E. Smith) (Lepidoptera: Noctuidae) a lambda-cialotrina. Neotropical Entomology, v.30, n.2, p.311-316, 2001. http://dx.doi.org/10.1590/ S1519-566X2001000200016

EBADOLLAHI, A. Iranian plant essential oils as sources of natural insecticide agents, International Journal of Biological Chemistry, v.5, n.5, p.266-290, 201 1. http://doi.org/10.3923/ ijbc.2011.266.290

ESTRELA, J.L.V.; FAZOLIN, M.; CATNI, V.; ALÉCIO, M.R.; LIMA, M.S. Toxicidade de óleos essenciais de Piper aduncum e Piper hispidinervum em Sitophilus zeamais. Pesquisa Agropecuária Brasileira, v.41, n.2, p.217-222, 2006. http://dx.doi. org/10.1590/SO100-204X2006000200005

FARIAS, J.R.; ANDOW, D.A.; HORIKOSHI, R.J.; SORGATTO, R.J.; FRESIA, P.; SANTOS, A.C.; OMOTO, C. Field-evolved resistance to Cry $1 \mathrm{~F}$ maize by Spodoptera frugiperda (Lepidoptera: Noctuidae) in Brazil. Crop Protection, v.64, p.150-158, 2014. https://doi. org/10.1016/j.cropro.2014.06.019
FILOMENO, C.A.; BARBOSA, L.C.A.; TEIXEIRA, R.R.; PINHEIRO, A.L.; FARIAS, E.S.F.; SILVA, E.M.P.; PICANÇO, M.C. Corymbia spp. and Eucalyptus spp. essential oils have insecticidal activity against Plutella xylostella. Industrial Crops and Products, v.109, p.374383, 2017. https://doi.org/10.1016/j.indcrop.2017.08.033

FRANCO. M.R.; SHIBAMOTO, T. Volatile Composition of some Brazilian fruits: umbu-caja (Spondias citherea), camu-camu (Myrciaria dubia), araça-boi (Eugenia stipitata), and Cupuaçu (Theobroma grandiflorum). Journal of Agricultural and Food Chemistry, v.48, n.4, p.1263-1265, 2000. https://doi.org/10.1021/jf9900074

GIATROPOULOS, A.; PAPACHRISTOS, D.P.; KIMBARIS, A.; KOLIOPOULOS, G.; POLISSIOU, M.G.; EMMANOUEL, N.; MICHAELAKIS, A. Evaluation of bioefficacy of three Citrus essential oils against the dengue vector Aedes albopictus (Diptera: Culicidae) in correlation to their components enantiomeric distribution. Parasitology Research, v. 11 1, n.6, p.2253-2263, 2012. https:// doi.org/10.1007/s00436-012-3074-8

GREENE, G.L.; LEPPLA, N.C.; DICKERSON, W.A. Velvetbean caterpillar: a rearing procedure and artificial medium. Journal of Economic Entomology, v.69, n.4, p.487-488, 1976. https:// doi.org/10.1093/jee/69.4.487

ISMAN, M.B. Plant essential oils for pest and disease management. Crop Protection, v.19, n.8-10, p.603-508, 2000. https://doi. org/10.1016/SO261-2194(00)00079-X

JANG, M.; KIM, J.; KYUNGIAE, A.Y.; HYEOCK, L.; CHUNG, G.P. Biological activity of Myrtaceae plant essential oils and their major components against Drosophila suzukii (Diptera: Drosophilidae). Pest Management Science, v.73, n.2, p.404-409, 2016. https:// doi.org/10.1002/ps.4430

KAUFMAN, P.E.; MANN, R.S.; BUTLER, J.F. Evaluation of semiochemical toxicity to Aedes aegypti, Ae. albopictus and Anopheles quadrimaculatus (Diptera: Culicidae). Pest Management Science, v.66, n.5, p.497-504, 2010. https://doi.org/10.1002/ps.1899

KRINSKI, D.; MASSAROLI, A.; MACHADO, M. Potencial inseticida de plantas da família annonaceae. Revista Brasileira de Fruticultura, v.36, n.spe 1, p.225-242, 2014. http://dx.doi.org/10.1590/ so $100-29452014000500027$

LEE, S.; PETERSON, C.J.; COATS, J.R. Fumigation toxicity of monoterpenoids to several stored product insects. Journal of Stored Products Research, v.39, p.77-85, 2003.

LORENZI, H.; MATOS, F.J. Plantas medicinais do Brasil: nativas e exóticas. 4. ed. Nova Odessa: Instituto Plantarum, 2008.

LUCENA, D.C.; BERTHOLDO-VARGAS, L.R.; SILVA, W.C.; MACHADO, A.F; LOPES, T.S.; MOURA, S.; BARROS, N.M. Biological Activity of Piper aduncum extracts on Anticarsia gemmatalis (Hübner) (Lepidoptera: Erebidae) and Spodoptera frugiperda(J.E. Smith) (Lepidoptera: Noctuidae). Anais da Academia Brasileira de Ciências, v.89, n.3, p.1869-1879, 2017. http://dx.doi.org/10.1590/0001-3765201720170194

LUZ, A.I.R.; DA SILVA, J.D.; ZOGHBI, M.G.B.; ANDRADE, E.H.A.; DA SILVA, M.H.L.; MAIA, J.G.S. Volatile constituents of Brazilian Piperaceae, Part 5. The oils of Pothomorphe umbellata y P. peltata. Journal of Essential Oil Research, v.1 1, n.4, p.479-481, 1999. https://doi.org/10.1080/10412905.1999.9701190 
MAIA, J.G.S.; ANDRADE, E.H.A. Database of the amazon aromatic plants and their essential oils. Química Nova, v.32, n.3, p.595-622, 2009. http://dx.doi.org/10.1590/ S0 $100-40422009000300006$

MARSARO JUNIOR, A.L.; SILVA JUNIOR, R.J. Insetos-pragas da cultura do milho em Roraima. Roraima: Embrapa, 2010. n.9. 1p.

MASTRANGELO, T.; PAULO, D.F.; BERGAMO, L.W.; MORAIS, E.G.F.; SILVA, M.; BEZERRA-SILVA, G.; AZEREDO, E. Detection and genetic diversity of a Heliothine Invader (Lepidoptera: Noctuidae) from north and northeast of Brazil. Journal of Economic Entomology, v.107, n.3, p.1-11, 2014. https://doi. org/10.1603/EC13403

MATTANA, R.S.; MAIA E ALMEIDA, C.I.; OLIVEIRA, P.F.C.; LIMA, L.P.; HABER, L.L.; MING, L.C.; MARQUES, M.O.M. Efeitos de diferentes tempos de extração no teor e composição química do óleo essencial de folhas de pariparoba [Pothomorphe umbellata (L.) Miq.]. Revista Brasileira de Plantas Medicinais, v.17, n.1, p.150156, 2015. http://dx.doi.org/10.1590/1983-084X/09_119

MEDEIROS, S.R.N.A.; MELO FILHO, A.A.; COSTA, H.N.R.; SILVA F.S.; SANTOS, R.C.; TAKAHASHI, J.A.; FERRAZ, V.P.; MELO, A.C.G.R.; RIBEIRO, P.R.E.; LARANJEIRA, A.G.A.; KAMEZAKI, A.K.; MARTINS, R.G.; PAULINHO, F.S. Chemical profile, antimicrobial activity, toxicity on Artemia salina and anti-acetylcholinesterase enzyme essential oil from Bauhinia ungulata L. (Fabaceae) leaves. Journal of Medicinal Plants Research, v.10, n.29, p.442-449, 2016. https://doi.org/10.5897/JMPR2016.6120

MELO, C.R.; PICANÇO, M.C.; SANOS, A.A.; SANTOS, I.B.; PIMENTEL, M.F.; SANTOS, A.C.C.; BLANK, A.F.; ARAÚJO, A.P.A; CRISTALDO, P.F.; BACCI, L. Toxicity of essential oils of Lippia gracilis chemotypes and their major compounds on Diaphania hyalinata and non-target species. Crop Protection, v.104, p.47-51, 2018. 10.1016/j. cropro.2017.10.013

MESQUITA, J.M.O.; CAVALEIRO, C.; CUNHA, A.P.; LOMBARDI, J.A.; OLIVEIRA, A.B. Estudo comparativo dos óleos voláteis de algumas espécies de Piperaceae. Brazilian. Journal of Pharmacognosy, v.15, n.1, p.6-12, 2005. http://dx.doi.org/10.1590/ S0102-695X2005000100003

NASCIMENTO, A.R.; FARIAS, J.R.; BERNARDI, D.; HORIKOSHI, R.J.; OMOTO, C. Genetic basis of Spodoptera frugiperda (Lepidoptera: Noctuidae) resistance to the chitin synthesis inhibitor lufenuron. Pest Management Science, v.72, n.4, p.810-815, 2016. https:// doi.org/10.1002/ps.4057

NICULAU, E.S.; ALVES, P.B.; NOGUEIRA, P.C.L. Atividade inseticida de óleo essenciais de Pelargonium graveolens l'Herit e Lippia alba (Mill) N. E. Brown sobre Spodeptera frugiperda (J.E. Smith). Química Nova, v.36, n.9, p.1391-1394, 2013. http://dx.doi. org/10.1590/SO100-40422013000900020

OLIVEIRA, A.P.; SANTANA, A.S.; SANTANA, E.D.R.; LIMA, A.P.; FARO, R.R.N.; NUNES, R.S.N.; LIMA, A.L.; BLANK, A.F.; ARAÚJO A.P.A.; CRISTALDO, P.F.; BACCI, L. Nanoformulation prototype of the essential oil of Lippia sidoides and thymol to population management of Sitophilus zeamais (Coleoptera: Curculionidae). Industrial Crops and Products, v.107, p.198-205, 2017 10.1016/j.indcrop.2017.05.046
OMOTO, C.; BERNARDI, O.; SALMERON, E.; SORGATTO, R.J.; DOURADO, P.M.; CRIVELLARI, A.; CARVALHO, R.A.; WILSE, A.; MARTINELLI, S.; HEAD, G.P. Field-evolved resistance to Cry $1 \mathrm{Ab}$ maize by Spodoptera frugiperda in Brazil. Pest Management Science, v.72, n.9, p.1727-1736, 2016. https:// doi.org/10.1002/ps.4201

PAVELA, R.; BENELLI, G. Ethnobotanical knowledge on botanical repellents employed in the African region against mosquito vectors - a review. Experimental Parasitology, v.167, p.103-108, 2016. https://doi.org/10.1016/j. exppara.2016.05.010

PITON, L.P.; TURCHEN, L.M.; BUTANARIU, A.R.; PEREIRA, M.J.B. Natural insecticide based-leaves extract of Piper aduncum (Piperaceae) in the control of stink bug brown soybean. Ciência Rural, v.44, n.1 1, p.1915-1920, 2014. http://dx.doi. org/10.1590/0103-8478cr20131277

POGUE, G.M. A world revision of the genus Spodoptera Guenée (Lepidoptera: Noctuidae). Memoirs of the American Entomological Society, Philadelphia, v.43, n.28, p.1-202. 2002.

RIBEIRO, A.V.; FARIAS, E.S.; SANTOS, A.A.; FILOMENO, C.A.; SANTOS, I.B.; BARBOSA, L.C.A.; PICANÇO, M.C. Selection of an essential oil from Corymbia and Eucalyptus plants against Ascia monuste and its selectivity to two non-target organisms. Crop Protection, v.110, p.207-213, 2018. http://doi.org/10.1016/j. cropro.2017.08.014

RITZ, C.; BATY, F.; STREIBIG, J.C.; GERHARD, D. Dose-response analysis using R. PlosOne, v.30, p.1-13, 2015. https://doi. org/10.1371/journal.pone.0146021

RITZ, C.; STREIBIG, J.C. Bioassay analysis using R. Journal of Statistical Software, v.12, n.5, p.1-22, 2005. http://doi. org/10.18637/jss.v012.iO5

ROEL, A.R.; VENDRAMIM, J.D.; FRIGHETTO, R.T.S.; FRIGHETTO, N. Efeito do extrato acetato de etila de Trichilia pallida swartz (meliaceae) no desenvolvimento e Sobrevivência da lagarta-do-cartucho. Bragantia, v.59, n.1, p.53-58, 2000. http://doi.org/10.1590/ s0006-87052000000100009

ROERSCH, C.M.F.B. Piper umbellatum L.: A comparative cross-cultural analysis of its medicinal uses and an ethnopharmacological evaluation. Journal of Ethnopharmacology, v.131, n.3, p.522-537, 2010. https://doi.org/10.1016/j. jep.2010.07.045

R CORE TEAM. R: A language and environment for statistical computing. Vienna, Austria: R Foundation for Statistical Computing, 2017. Available from: https://www.R-project.org/

SANTOS, J.S.; MELO, J.I.M.; ABREU, M.C.; SALLES, M.F. Verbenaceae sensu stricto na região de Xingó: Alagoas e Sergipe, Brasil. Rodriguésia, v.60, n.4, p.985-998, 2009. http://dx.doi. org/10.1590/2175-7860200960412

SAKAZAKI, R.T.; ALVEZ, J.M.; LOPES, G.N. Arroz irrigado em Roraima. Agroambiente, v.2, n. 1, p.69-76, 2008. http://dx.doi. org/10.18227/1982-8470ragro.v2i 1.166 
SCOTT, I.M.; JENSEN, H.R.; PHILOGÉNE, B.J.R.; ARNASON, J.T. A review of Piper spp. (Piperaceae) phytochemistry, insecticidal activity and mode of action. Phytochemistry Reviews, v.7, p.6575, 2008. https://doi.org/10.1007/s $11101-006-9058-5$

SILVA, M.M. Estudo da composição química do óleo essencial de Lippia microphylla CHAM em três anos diferentes e atividade antioxidante. 2014.69p. Dissertação (Mestrado em Química) Programa de Pós-Graduação em Química, Universidade Federal de Roraima, Boa Vista, 2014.

SIMÕES, E.R.B.; SANTOS, E.A.; ABREU, M.C.; SILVA, J.N.; NUNES, N.M.F.; COSTA, M.P.; PESSOA, O.D.L.; PESSOA, C.; FERREIRA, P.M.P. Biomedical properties and potentiality of Lippia microphylla CHAM. and its essential oils. Journal of Intercultural Ethnopharmacology, v.4, n.3, p.256-263, 2015. http://dx.doi. org/0.5455/jice.20150610104841

SOUZA, T.F.; FAVERO, S.; CONTE, C.O. Bioatividade de óleos essenciais de espécies de eucalipto para o controle de Spodoptera frugiperda (J. E. Smith, 1797) (Lepidoptera: Noctuidae). Revista Brasileira de Agroecologia, v.5, n.2, p.157-164, 2010.
VIANA, P.A.; PRATES, H.T. Desenvolvimento e mortalidade larval de Spodoptera frugiperda em folhas de milho tratadas com extrato aquoso de folhas de Azadirachta indica. Bragantia, v.62, n.1, p.69-74, 2003. http://dx.doi.org/10.1590/ s0006-87052003000100009

VIEGAS JÚNIOR, C. Terpenos com atividades inseticidas: uma alternativa para o controle químico de insetos. Química Nova, v.26, n.3, p.390-400, 2003. http://dx.doi.org/10.1590/ so $100-40422003000300017$

ZHANG, Z:; ZONGXIU, L.; GAO, Y.; LEI, B.; XIAOLING, S.; ZONGMAO, C. Volatiles from non-host aromatic plants repel tea green leafhopper Empoasca vitis. Entomologia Experimentalis et Applicata, v.153, n.2, p.156-169, 2014. https://doi.org/10.1111/eea.12236

XAVIER, A.L.; PITTA, J.C.L.R.; BRITO, M.T.; MEIRELES, D.R.P.; TAVARES, J.F.; SILVA, S.M.; MAIA, J.G.S.; ANDRADE, E.H.A.; DINIZ, M.F.F.M.; SILVA, T.G.; PESSOA, H.L.F.; SOBRAL, M.V. Chemical composition, antitumor activity, and toxicity of essential oil from the leaves of Lippia microphylla. Zeitschrift für Naturforschung, v.70, n.5-6, p.129-137, 2015. https://doi.org/10.1515/znc-2014-4138 